\title{
PENGARUH STRATEGI PEMBELAJARAN DAN KONSEP DIRI TERHADAP KETERAMPILAN SMASH BULUTANGKIS
}

\author{
Andi Taufan ${ }^{(1)}$ Bayu Dewantara ${ }^{(2)}$ Alsaudi ${ }^{(3)}$ \\ STKIP Kusuma Negara Cijantung Jakarta Timur \\ E-mail: anditaufan16.at@gmail.com
}

\begin{abstract}
ABSTRAK
Penelitian ini bertujuan untuk mengetahui perbandingan pengaruh antara penggunaan gaya mengajar latihan dan gaya mengajar komando dengan konsep diri terhadap keterampilan smash bulutangkis pada siswa kelas X SMA ADI LUHUR Jakarta Timur. Hasil penelitian menunjukkan pertama, terdapat perbedaan hasil keterampilan smash bulutangkis antara gaya mengajar latihan dengan gaya mengajar komando secara keseluruhan didapat $\mathrm{Fh}=53.34$ dan $\mathrm{Ft}$ $=4,00$, Dengan demikian Fo $>\mathrm{Ft}$, sehingga Ho ditolak, sehingga dapat disimpulkan bahwa secara keseluruhan, terdapat perbedaan yang nyata antara gaya mengajar latihan dan gaya mengajar komando terhadap hasil keterampilan smash. Kedua, terdapat perbedaan hasil keterampilan smash bulutangkis antara gaya mengajar latihan dan gaya mengajar komando bagi kelompok konsep diri tinggi diperoleh $\mathrm{Qh}=5,25$ dan $\mathrm{Qt}=1.70$. Dengan demikian $\mathrm{Qh}$ lebih besar dari Qt, sehingga Ho ditolak. Ketiga, terdapat perbedaan hasil keterampilan smash bulutangkis antara gaya mengajar latihan dan gaya mengajar komando bagi kelompok konsep diri rendah diperoleh hasil, $\mathrm{Qh}=-2,01<\mathrm{Qt}=1.70$. Artinya, Ho diterima, dan H1 ditolak. Keempat, terdapat interaksi antara gaya mengajar dan konsep diri terhadap hasil keterampilan smash bulutangkis diperoleh harga hitung Fo interaksi $(\mathrm{FAB})=53,34$ dan $\mathrm{F}$ tabel $=4.00$. Tampak bahwa F hitung > F tabel, sehingga H0 ditolak. dan H1 diterima. Kesimpulan analisis secara keseluruhan, gaya mengajar latihan memiliki pengaruh lebih baik jika dibandingkan dengan gaya mengajar komando terhadap hasil belajar keterampilan smash bulutangkis pada siswa kelas X SMA ADI LUHUR Jakarta Timur.
\end{abstract}

Kata Kunci: Gaya Mengajar Latihan, Gaya Mengajar Komando, Konsep Diri, Hasil Keterampilan Smash Bulutangkis.

\section{PENDAHULUAN}

Pendidikan merupakan bentuk usaha manusia dalam mempertahankan keberlangsungan kehidupan maupun budayanya, melalui pendidikan maka dinamika kehidupan manusia yang beraneka ragam dapat diatur dan diarahkan menuju perubahanperubahan pada situasi dan kondisi yang lebih baik. Pendidikan jasmani menjadi upaya pendidikan sebagai sebuah kegiatan yang bersifat mendidik, dan upaya itu berlangsung melalui aktifitas jasmani sebagai wahana dan medianya, ciri umum diatas meliputi adanya interaksi antara pendidik dan peserta didik yang berlangsung dalam hubungan pergaulan yang bersifat mendidik. Pihak pendidik atau guilt memiliki kewenangan berdasarkan kewibawaan yang dimilikinya secara sadar untuk melancarkan pengaruh terhadap siswa sebagai peserta didik, berlangsung melalui pengalaman belajar yang merespon siswa untuk dapat menghasilkan perubahan prilaku secara keseluruhan yang dicakup dalam aspek kognitif, afektif dan psikomotor. 
Pembelajaran yang dapat mengembangkan potensi anak antara lain yaitu pembelajaran terpadu. Hal tersebut didasarkan pada perkembangan anak secara holistik, berlangsung secara terpadu (aspek dimensi satu mempengaruhi aspek dimensi yang lain). Dalam pembelajaran terpadu guru dituntut untuk memiliki kemampuan dalam merancang dan melaksanakan pembelajaran yang sesuai dengan karakteristik anak agar dapat mengikuti perkembangan jaman yang semakin maju. Salah satu olahraga permainan yang telah memasyarakat di Indonesia adalah permainan bulutangkis, selain dapat dijadikan sebagai olahraga prestasi, juga dapat menjadi olahraga rekreasi. Hampir dalam setiap pesta-pesta olahraga, mulai dari pesta olahraga ditingkat Rukun Tetangga (RT) atau Rukun Warga (RW), sekolah-sekolah, sampai tingkat nasional, regional, bahkan tingkat Internasional, permainan bulutangkis termasuk di dalamnya.

Bulutangkis sebagai salah satu cabang olahraga yang digemari oleh masyarakat perlu memainkan peran dalam pembangunan bidang olahraga seoptimal mungkin. Permainan bulutangkis yang dilakukan oleh Persatuan Bulutangkis Seluruh Indonesia (PBSI) adalah suatu kegiatan yang sangat kompleks. Lebih-lebih terkait dengan tuntutan masyarakat akan prestasi bulutangkis dengan menambah beban pembinaan tersebut. Untuk menghadapi persaingan yang terjadi dalam bidang olahraga khususnya pada cabang olahraga bulutangkis, maka pola pembinaan yang dilakukan harus lebih terencana, sistematis dan konseptual. Prestasi akan tercapai apabila seorang pemain akan dibina sejak usia dini, secara ilmiah, kontinyu, bertahap, dan berkesinambungan selama kurang lebih 10 tahun. Karena usia emas "gold age" prestasi puncak cabang olahraga berkisar antara umur 20-25 tahun. Penguasaan teknik dasar bulutangkis yang benar merupakan salah satu pembinaan pada jenjang Sekolah Menengah Atas (SMA). Bermain bulutangkis dengan baik diperlukan keterampilan dasar bermain bulutangkis yang baik.

Keterampilan smash yang tajam dan mematikan diperlukan untuk dimiliki oleh setiap pemain bulutangkis bukan hanya dalam permainan tunggal saja akan tetapi juga dalam permainan ganda. Khusus pemain ganda keterampilan ini tidak bisa ditawartawar lagi ini merupakan yang harus dimiliki oleh setiap pemain dalam upaya menekan lawan untuk mendapatkan angka semaksimal mungkin. Dalam hal ini sejalan dengan pendapat Ralph Ballou yang mengemukakan bahwa smash adalah poin yang sangat penting dalam mematikan lawan pada saat bertanding (Ballou, 1992). Keterampilan smash adalah suatu keterampilan yang paling utama untuk mengakhiri sebuah rally dalam permainan bulutangkis, oleh karena itu untuk mencapai prestasi yang maksimal mutlak keterampilan smash ini harus dimiliki oleh pemain.

Siswa adalah merupakan kelompok generasi muda yang dapat diprediksi menjadi bakal calon atlet berupa bibit-bibit baru yang berbakat, yang perlu dididik dengan aktivitas olahraga, agar mereka berbadan sehat dan dapat mencapai prestasi yang menggembirakan. Oleh sebab itu pembinaan prestasi olahraga perlu mendapat perhatian oleh para guru penjas dari masing-masing jenjang pendidikan mulai dari Sekolah Dasar (SD), Sekolah Menengah Pertama (SMP), Sekolah Menengah Atas (SMA), yaitu melalui pendidikan jasmani Olahraga dan Kesehatan di sekolah. Dalam Kurikulum Berbasis Kompetensi (KBK) dan kini Kurikulum Tingkat Satuan Pendidikan (KTSP) yang diselenggarakan di sekolah saat ini, mata pelajaran pendidikan jasmani yang sesuai dengan fungsinya, yakni mengembangkan dan meningkatkan kemampuan organic, neoromuskuler, interperatif, sosial, dan emosional terdapat kemungkinan pada 
anak didik untuk mengembangkan bakat dan keinginannya serta mempertahankan prestasi.

Setiap siswa mempunyai hak untuk mencapai potensinya masing-masing sehingga strategi mengajar harus memberikan kesempatan kepada siswa agar memperoleh pengalaman sebagaimana yang dikehendaki. Para siswa harus berkembang dalam kecepatan yang sesuai dengan iramanya, dan strategi mengajar harus mampu meningkatkan perkembangan penguasaan keterampilan mereka. Perbedaan-perbedaan individual harus menjadi pedoman dalam menerapkan strategi mengajar, sehingga tujuan, kegiatan, dan pengalaman belajar dapat memenuhi kebutuhan individual dari para siswa. Guru hendaknya bertanggung jawab dalam mengembangkan aspek-aspek yang lengkap dari siswa, bukan saja keterampilan fisik dan kebugaran jasmani, tetapi mencakup keterampilan kognitif dan keterampilan sosial. Dalam wilayah kognitif misalnya, pembelajaran yang terpadu harus sejalan dengan perkembangan kebugaran fisik dan keterampilan. Demikian juga dalam wilayah afektif, pencapaian keberhasilan yang bersifat fisik memainkan peran yang amat penting dalam mengembangkan konsep diri yang positif. Anak-anak yang mencapai efisiensi gerak dan berhasil dalam keterampilannya, akan lebih mudah menyesuaikan dirinya dalam kehidupan sekolahnya dari pada yang kurang mampu secara gerak. Kegiatan pembelajaran pendidikan jasmani yang dilaksanakan harus meyakinkan bahwa nilai-nilai yang terkandung dalam pendidikan jasmani tidak dicapai secara otomatis atau kebetulan saja. Namun sifat-sifat seperti kejujuran, fair-play, disiplin diri, dan kerjasama kelompok dapat terbentuk melalui program pengajaran yang memanfaatkan strategi mengajar yang bernuansa pendidikan. Penerapan model pembelajaran pendidikan jasmani dalam kegiatan pembelajaran sehari-hari, sebenarnya guru penjas sudah melaksanakan gaya mengajar latihan dan gaya mengajar komando, namun proses pelaksanaannya masih bersifat tradisional. Guru pendidikan jasmani kurang memahami dan belum kreatif dalam memilih gaya mengajar yang tepat untuk siswanya. Misalnya pada gaya mengajar komando guru penjas biasanya menerapkannya untuk semua, padahal belum tentu gaya mengajar ini cocok untuk semua siswa. Dalam kegiatan ini guru telah mempersiapkan standar bagi semua siswa dalam kegiatannya. Karena dalam satu komando, maka tidak akan timbul semangat bersaing, sehingga tidak terdapat perbedaan individu. Seharusnya setiap menggunakan suatu gaya mengajar, guru harus memperhatikan tingkat perkembangan dan kemampuan siswa dalam menyerap materi yang diberikan guru.

\section{METODE PENELITIAN}

Metode yang digunakan dalam penelitian ini adalah metode eksperimen lapangan. Sebagaimana yang dikemukakan oleh Winarno bahwa, metode eksperimen lapangan adalah metode yang hendak menemukan faktor-faktor sebab akibat, mengontrol peristiwa-peristiwa dalam interaksi variabel-variabel serta meramalkan hasil-hasilnya pada tingkat tertentu (Winarno, 1989:149). Teknik pengambilan sampel dengan cara random sampling diambil sebanyak 60 siswa dari jumlah populasi 112 siswa kemudian sampel dibagi menjadi empat kelompok. Kelompok pertama dengan jumlah 15 siswa bagi kelompok konsep diri tinggi yang diajar dengan gaya mengajar latihan, kelmpok kedua dengan jumlah 15 siswa bagi kelompok konsep diri rendah yang diajar dengan gaya mengajar latihan, kelompok ketiga dengan jumlah 15 siswa bagi kelompok konsep diri tinggi yang diajar dengan gaya mengajar komando dan kelompok 
keempat dengan jumlah 15 siswa bagi kelompok konsep diri rendah yang diajar dengan gaya mengajar komando.

Instrumen penelitian ini adalah hasil keterampilan smash bulutangkis dengan baik dan benar, terlebih dahulu instrument diuji validitas dengan face validity. Teknik pengolahan data hasil penelitian menggunakan statistik uji normalitas, uji homogenitas, uji anava dua jalur dan uji kelanjutan hipotesis dengan menggunakan uji tukey.

\section{HASIL DAN PEMBAHASAN}

Pengujian hipotesis pertama membuktikan adanya perbedaan antara gaya mengajar latihan secara keseluruhan dengan gaya mengajar komando secara keseluruhan. Dan gaya mengajar latihan memberikan pengaruh labih baik terhadap hasil belajar keterampilan smash bulutangkis. Ini berarti bahwa kedua gaya mengajar memberikan pengaruh yang berbeda terhadap hasil belajar keterampilan smash bulutangkis, dan gaya mengajar latihan lebih efektif untuk menghasilkan keterampilan smash bulutangkis pada siswa kelas X SMA ADI LUHUR Jakarta Timur.

Pengujian hipotesis kedua membuktikan bahwa pada kelompok siswa yang memiliki tingkat konsep diri tinggi bagi siswa yang diajar dengan gaya mengajar latihan terdapat pengaruh yang signifikan dengan siswa yang diajar dengan gaya mengajar komando. Oleh karena itu hipotesis ini membuktikan bahwa pada kelompok siswa yang memiliki tingkat konsep diri tinggi yang diajar dengan gaya mengajar latihan terhadap keterampilan smash lebih baik dari pada siswa yang diajar dengan gaya mengajar komando. Oleh karena itu akan di lanjutkan dengan uji Tukey.

Pengujian hipotesis ketiga menunjukkan bahwa pada kelompok siswa yang memiliki tingkat konsep diri rendah terhadap keterampilan smash yang diajar dengan gaya mengajar komando dan gaya mengajar latihan, tidak memberikan perbedaan yang signifikan. Oleh karena itu pada kelompok siswa yang memiliki tingkat konsep diri rendah yang diajar dengan gaya mengajar latihan dan gaya mengajar komando memberikan perbedaan dari hasil keterampilan smash pada siswa kelas X SMA ADI LUHUR Jakarta Timur.

Pengujian hipotesis keempat membuktikan bahwa terdapat interaksi antara strategi pembelajaran dan konsep diri terhadap hasil belajar keterampilan smash bulutangkis. Dengan pemilihan strategi pembelajaran yakni: gaya mengajar latihan memberikan hasil belajar keterampilan smash bulutangkis yang lebih baik dari pada gaya mengajar komando. Sedangkan pemilihan antara strategi pembelajaran dari konsep diri tidak dapat meningkatkan keterampilan smash bulutangkis pada siswa kelas X SMA ADI LUHUR Jakarta Timur.

Dengan demikian dapatlah dinyatakan bahwa secara keseluruhan gaya mengajar latihan memiliki pengaruh lebih baik jika dibandingkan dengan gaya mengajar komando. Sedangkan bagi yang memiliki tingkat konsep diri rendah, dapat melakukan latihan atau belajar untuk meningkatkan keterampilan smash bulutangkis yang lebih baik, akan tetapi cenderung akan lebih baik lagi jika melakukan proses belajar dengan menggunakan gaya mengajar latihan.

Keterampilan bulutangkis merupakan salah satu cabang olahraga permainan yang sangat popular dan banyak digemari masyarakat di Indonesia, bahkan di seluruh dunia. Permainan ini menggunakan raket sebagai alat pemukul dan shuttlecock sebagai objek pukul, dapat dimainkan pada lapangan tertutup maupun terbuka. Lapangan permainan berbentuk empat persegi panjang yang ditandai dengan garis, serta dibatasi 
oleh net untuk memisahkan antara daerah permainan sendiri dan permainan lawan. permainan ini bersifat individual, dapat dimainkan satu orang melawan satu orang atau dua orang melawan dua orang. Dapat dimainkan oleh putera, puteri, dapat pula dimainkan oleh pasangan campuran putera dan puteri.

Permainan bulutangkis sangat menarik dan relatif mudah dimainkan, karena selain raketnya relatif ringan juga untuk memainkannya untuk rekreasi tidak memerlukan latihan yang terlalu lama. Sehingga banyak orang yang melakukan permainan bulutangkis untuk kesenangan dan kegiatan rekreasi. Selain itu banyak juga orang bermain bulutangkis dengan tujuan untuk memelihara kebugaran jasmani dan kesehatan. Bahkan saat ini beberapa perkumpulan bulutangkis mempersiapkan atlet sejak dini untuk menghasilkan etlet potensial dan berprestasi pada masa yang akan datang.

Agar dapat bermain bulutangkis, seorang pemain harus menguasai berbagai teknik dasar permainan dengan benar, yang meliputi pegangan raket, olah kerja kaki, serta berbagai teknik dasar pukulan. Upaya untuk menguasai berbagai teknik dasar permainan tersebut diperoleh melalui proses pembelajaran.

Dalam pembelajaran bulutangkis, inti kegiatan belajar siswa berupa berbagai aktivitas gerak fisik yang tersusun dalam pola gerak untuk melakukan berbagai keterampilan bulutangkis, melalui aktivitas gerak fisik yang beragam tersebut siswa memperoleh pengalaman gerak, yang pada gilirannya akan membuahkan perubahan perilaku terampil yang dapat diamati dan diukur sebagai keterampilan.

Aktivitas belajar gerak dalam bulutangkis berupa penguasaan berbagai macam teknik dasar pegangan (grip), olah kerja kaki (foot work), dan berbagai jenis pukulan (strokes), yang terdiri dari: pukulan atas kepala (overhead strokes), pukulan samping (side arm strokes), dan pukulan-pukulan bawah (under arm strokes), pukulan atas kepala (overhead), terdiri dari lob (clear), drop shots dan smash. pukulan samping (side arm), terdiri dari drive dan drop shots. Sedangkan pukulan bawah (under arm), terdiri dari servis pendek (short service), servis panjang (long service), underhand lob, underhand drop shots dan netting (Arisanto et.al., 1990).

a. Teknik Dasar Pegangan Raket (Grip).

Bulutangkis dikenal sebagai olahraga yang banyak menggunakan pergelangan tangan. Benar tidaknya cara memegang raket akan sangat menentukan kualitas pukulan seseorang. Oleh karena itu salah satu teknik dasar bulutangkis yang sangat penting dikuasai secara benar oleh setiap calon pebulutangkis adalah pegangan raket. Menguasai cara dan teknik pegangan raket yang benar, merupakan modal penting untuk dapat bermain bulutangkis dengan baik. Apabila teknik pegangan raket salah sejak awal, maka sulit untuk diperbaiki. Pegangan raket yang benar adalah raket harus dipegang dengan menggunakan jari-jari tangan (ruas jari tangan) dengan luwes, rileks, namun harus tetap bertenaga pada saat memukul kok. Hindari pegangan raket dengan cara menggunakan telapak tangan (seperti cara memegang golok atau kapak), (Djide, 2003:10). Pegangan raket dengan cara seperti jabat tangan. Bentuk "V" tangan yang dibuat oleh ibu jari dan telunjuk diletakkan pada gagang raket, lalu ke tiga jari, yaitu jari tengah, manis, dan kelingking menggenggam raket, sedangkan jari telunjuk agak terpisah, kemudian letakkan ibu jari di antara tiga jari dan telunjuk.

Selain itu pegangan dengan cara ini dapat menghasilkan pukulan yang cukup keras namun gerakan nampak kaku, juga sangat sulit digunakan untuk pukulan backhand, (Poole, 2005:17). 
Pegangan ini terutama dipakai dalam permainan ganda dekat net. Pegangan ini mengurangi kemungkinan meukul net, karena ayunan raket hampir selalu sejajar dengan bagian atas net. Pegangan ini dulunya sangat popular di Amerika Serikat. Khusus di Indonesia pegangan dengan cara ini kurang disenangi, bahkan ada sebagian pelatih menganggap salah. Kelemahan pegangan ini di antaranya pegangan pukul kasur dapat dilakukan dengan cara sebagai berikut : 1. Letakkan raket dengan posisi kepala raket mendatar, sejajar dengan lantai, 2. Pegangan dengan posisi huruf "V" tangan berada pada bagian yang lebar dari pegangan raket.

Dengan demikian yang dimaksud dengan keterampilan bulutangkis dalam penelitian ini adalah kemampuan seseorang untuk melakukan teknik-teknik dasar pukulan, yang diperoleh setelah siswa mengikuti proses pembelajaran bulutangkis secara khusus penelitian ini terfokus pada teknik pukulan smes (smash).

b. Keterampilan Pukulan Smash.

Pukulan smash dalam bulutangkis, adalah bentuk pukulan keras yang sering digunakan dalam permainan bulutangkis. Jika pukulan lainnya digunakan untuk memancing lawan, merusak posisi lawan atau membuka daerah permainan lawan, maka pukulan smash ditujukan untuk mengakhiri suatu rally dengan cara memukul bola sekeras mungkin ke bidang permainan lawan. betapapun sempurnanya seseorang melakukan berbagai macam pukulan, menjadi sia-sia manakala tanpa dilengkapi dengan pukulan smash yang bermutu.

Pukulan smash adalah, pukulan overhead (atas) yang diarahkan ke bawah dan dilakukan dengan tenaga penuh. Pukulan ini identik sebagai pukulan menyerang. Karena itu tujuan utamanya adalah untuk mematikan lawan. karakteristik pukulan ini adalah; keras, laju jalannya shuttle cock sangat cepat menuju lapangan permainan lawan, sehingga pukulan ini membutuhkan aspek kekuatan otot tungkai, bahu lengan dan fleksibilitas pergelangan tangan serta koordinasi gerak tubuh yang harmonis, (Djide, 2003:30). Pukulan smash terdiri dari dua macam, yaitu pukulan smash penuh (full smash), dan pukulan smash potong (half smash). pukulan smash penuh tidak selalu dapat mematikan lawan, seringkali pukulan setengah smash mudah lebih berhasil apabila dilakukan pada saat yang tepat. Cara melakukannya sama dengan pukulan smash penuh, hanya pada saat raket akan menyentuh bola, bola agak sedikit dipotong.

Cara melakukan pukulan smash adalah sebagai berikut :

a. Tahap persiapan

b. Tahap pelaksanaan

c. Tahap akhir

Keterampilan smash merupakan salah satu teknik dasar dalam permainan bulutangkis yang dilakukan dengan pukulan yang sangat kuat, tajam dan menghujam masuk kedaerah lapangan lawan, bertujuan utuk mematikan permainan lawan secepat cepatnya dalam suatu permainan bulutangkis.

Keterampilan smash adalah keterampilan yang dilakukan dari atas kepala dari hasil bola yang dipukul lob oleh lawan. keterampilan ini dapat dilakukan dengan forehand ataupun backhand, akan tetapi umumnya keterampilan smash dilakukan dengan posisi forehand karena dengan keterampilan forehand dimungkinkan pemain dapat melakukan keterampilan ini dengan cepat dan kuat. Senada dengan pernyataan di atas Kenneth R. Davidson dan Lealand R. Gustavson mengemukakan bahwa keterampilan smash adalah keterampilan yang dilakukan dari atas kepala yang 
memungkinkan member kesempatan untuk dipukul menukik ke bawah dengan kecepatan maksimum melalui atas net. (Davidson dan Gustavson, 1964:49).

Keterampilan smash terjadi karena adanya kontraksi teknik dasar melakukan keterampilan smash dimulai dengan menarik kaki kanan ke belakang, posisi bahu kiri menghadap lawan, berat badan berada pada kaki kanan, tangan kiri diangkat untuk menjaga keseimbangan.

Setelah seorang pemain dapat melakukan keterampilan smash dengan teknik dasar yang benar, dalam pengembangannya seorang pemain dapat melakukan smash dengan cara melompat untuk menjangkau bola setinggi mungkin. Para pemain berprestasi khususnya para pemain dari kawasan asia, mereka terbiasa melakukan keterampilan smash dengan cara melompat atau lazim dikatakan "jumping smash". Hal ini sejalan dengan pendapat Steve Baddeley yang menjelaskan bahwa dalam permainan tingkat tinggi dimungkinkan untuk melakukan smash dengan lompatan. Smash lompatan tersebut dipopulerkan oleh pemain-pemain dari timur, beberapa diantaranya melakukan keterampilan smash sambil terbang. Dengan melakukan keterampilan smash sambil melompat akan sangat menguntungkan, karena titik perkenaan bola dengan raket akan terjadi lebih tinggi, hal ini akan membuat jalannya bola lebih tajam dan menukik, dan pada gilirannya akan dapat dengan mudah mematikan permainan lawan.

Berdasarkan pendapat diatas maka dapat disimpulkan bahwa keterampilan pukulan smash bulutangkis adalah kemampuan yang dilakukan dalam tempo yang singkat pukulan yang membutuhkan tenaga penuh dari impact dengan raket sampai dengan shuttlecocks menyentuh lantai daerah lapangan lawan dengan tujuan untuk mengirim shuttlecocks ke tempat daerah pertahanan lawan dengan secepat mungkin baik untuk memberikan tekanan maupun untuk mematikan lawan dalam bermain.

Secara umum strategi adalah alat, rencana atau metode yang dipergunakan untuk menyelesaikan suatu tugas. (Beckman, 2004:1). Dalam konteks pembelajaran, strategi berkaitan dengan pendekatan dalam penyampaian materi pada lingkungan pembelajaran. Untuk itu strategi harus disesuaikan dengan tujuan-tujuan pembelajaran yang telah ditentukan.

Strategi pembelajaran sebagai pola aktivitas guru dan siswa, seyogyanya memuat sejumlah komponen yang membentuk jalinan keterkaitan dalam wadah yang disebut dengan pola pembelajaran. Dick dan Carey memandang strategi pembelajaran sebagai penjelasan tentang komponen-komponen umum dari seperangkat materi pembelajaran dan prosedur yang akan digunakan bersama bahan-bahan tersebut, untuk mencapai suatu hasil belajar tertentu pada siswa (Dick dan Carey, 1996:183). Komponen dari strategi pembelajaran tersebut adalah kegiatan pembelajaran, penyajian informasi, partisipasi siswa, tes dan tindak lanjut.

Dalam perencanaan strategi pembelajaran, terdapat lima tahapan yang harus dilalui, yaitu 1. Menyeleksi media yang sesuai dengan tujuan, mengurutkan dan mengelompokkan tujuan, 2. Merencanakan pra-pembelajaran, 3. Tes dan aktivitas tindak lanjut, 4. Merencanakan penyajian informasi dan partisipasi siswa pada setiap bagian pembelajaran, dan 5. Menentukan aktivitas untuk pelajaran dan mengestimasi waktu yang dibutuhkan untuk setiap pelajaran.

Dari pendapat para ahli di atas, maka disimpulkan bahwa strategi dapat diartikan sebagai perencanaan yang berisi tentang rangkaian kegiatan yang didesain untuk mencapai tujuan pendidikan tertentu. Strategi digunakan untuk memperoleh kesuksesan atau keberhasilan dalam mencapai tujuan. Strategi pembelajaran pada hakekatnya 
berkenaan dengan : 1. Urutan kegiatan pembelajaran, yakni tahap-tahap yang perlu dilalui dalam penyajian materi pembelajaran; 2 . Metode atau teknik pembelajaran, yaitu prosedur teknis pengorganisasian bahan dan pengelolaan pelajar dalam proses pembelajaran; 3. Media pembelajaran, yaitu peralatan dan bahan pembelajaran yang digunakan sebagai media dalam proses pembelajaran, dan 4. Definisi peran, yakni pembagian peran atau fungsi antara guru dan siswa dalam proses pembelajaran.

Dalam proses pengajaran diharapkan dapat meningkatkan kemampuan masingmasing siswa dalam menyampaikan gagasan pribadinya. Oleh karena itu seorang guru dituntut agar dapat menciptakan jembatan atau perantara yang dapat menghubungkan siswa dengan materi pelajaran, serta keharmonisan dari semua pihak dalam kegiatan tersebut, baik guru, materi pelajaran maupun siswanya.

Pada umumnya proses pembelajaran di sekolah ini masih berjalan klasikal, artinya seorang guru dalam kelas menghadapi sejumlah besar siswa (antara $30-40$ orang) dalam waktu yang sama menyampaikan bahan pelajaran yang sama pula. Bahkan metodenya pun satu metode yang sama untuk seluruh siswa tersebut. dalam pembelajran klasikal seperti ini guru beranggapan bahwa seluruh siswa satu kelas itu mempunyai kemampuan (ability), kesiapan dan kematangan (maturity), dan kecepatan belajar yang sama. Pandangan seperti ini perlu dirubah, sebagaimana dijelaskan oleh Pestaloozzi yang dikutip Suryosubroto, bahwa dalam proses pembelajaran anak harus diperlakukan seperti manusia, harus dididik sesuai dengan kebutuhannya, dan belajar sesuatu yang berguna bagi dirinya (Suryosubroto, 2009:71).

Dengan demikian yang dimaksud dengan gaya mengajar dalam penelitian ini adalah kemampuan menggunakan berbagai cara untuk mensiasati sistem pengajaran sehingga tujuan proses pembelajaran dapat tercapai secara efektif dan efisien.

Gaya mengajar latihan merupakan salah satu model pengajaran yang cocok diterapkan dalam pendidikan jasmani karena memiliki beberapa manfaat, antara lain : 1 . Guru akan mempunyai peluang untuk mengajar dalam jumlah siswa yang banyak sekaligus; 2. Siswa belajar untuk bisa bekerja secara mandiri; 3. Siswa mempelajari konsekuensi atas keputusan yang mereka buat sesuai dengan ketentuan yang ada; 4. Siswa belajar mengenai keterbatasan waktu; 5 . Siswa belajar mengenai sasaran yang harus dicapai dengan melaksanakan tugas-tugas tertentu; dan 6. Siswa memiliki kesempatan untuk meningkatkan interaksi individual dengan setiap siswa lainnya.

Ciri utama dari gaya mengajar latihan adalah selama pertemuan berlangsung ada beberapa keputusan yang ditransfer dari guru pada siswa. Pemindahan tersebut memberi peranan dan perangkat tanggung jawab baru kepada siswa. Setiap siswa mempunyai kesempatan untuk menentukan cara membuat keputusan sendiri, dengan tetap memperhatikan ketentuan yang ada, diantaranya : 1. Sikap (postur), 2. Tempat, 3. Urutan pelaksanaan tugas, 4. Waktu untuk memulai tugas, 5. Kecepatan dan irama, 6. Waktu berhenti, 7. Waktu selang di antara tugas-tugas, 8. Memprakarsai pertanyaanpertanyaan.

Pengajaran dengan gaya latihan di desain untuk meningkatkan keterampilan siswa dengan cara menugaskan siswa untuk melakukan berbagai latihan secara berulang-ulang. Dengan pengulangan kegiatan tersebut diharapkan dapat meningkatkan fisik serta keterampilan siswa yang sedang dilatih.

Sasaran yang berhubungan dengan tugas penampilan antara lain : 1. Berlatih tugas-tugas yang telah diberikan sebagaimana yang telah didemonstrasikan dan dijelaskan; 2. Memperagakan/mendemonstrasikan tugas penampilan yang diberikan; 3 . 
Lamanya waktu yang berkaitan dengan kecakapan penampilan; 4. Memiliki pengalaman dan pengetahuan tentang hasil yang diberikan guru dalam berbagai bentuk. Anatomi gaya latihan yang digambarkan oleh Mosston sebagai berikut.

Tabel 1. Anatomi Gaya Mengajar Latihan, Mosston, (1994:32)

\begin{tabular}{cc}
\hline Perangkat Keputusan & B \\
\hline Pra pertemuan & $(\mathrm{G})$ \\
\hline Selama pertemuan & $(\mathrm{S})$ \\
\hline Pasca pertemuan & $(\mathrm{G})$ \\
\hline
\end{tabular}

Keterangan :

$\mathrm{B}=$ Gaya latihan

$\mathrm{G}=\mathrm{Guru}$

$\mathrm{S}$ = Siswa

Sesuai dengan anatomi tersebut di atas maka peran guru dan siswa dapat dijabarkan sebagai berikut :

Sebelum pertemuan (G) : guru menjelaskan desain lembar tugas yang berisi apa yang harus dilakukan siswa dan bagaimana cara melakukannya, dengan berfokus pada tugas. Selama pertemuan berlangsung (S) : 1. Siswa menerima tugas, 2. Siswa membuat keputusan mengenai : sikap/postur, tempat, urutan pelaksanaan tugas, waktu untuk memulai tugas, waktu berhenti, kecepatan dan irama, waktu sela di antara tugastugas, dan memprakarsai pertanyaan-pertanyaan. Sedangkan guru hanya mengawasi pelaksanaan tugas oleh siswa, dan mengamati kesulitan ataupun kendala yang dihadapi oleh siswa. Pasca pertemuan (G) : guru member umpan balik kepada seluruh siswa.

Esensi dari pengajaran dengan gaya latihan meliputi : 1. Materi pelajaran diberikan secara utuh dengan penjelasan langsung maupun melalui lembar tugas, 2. Latihan yang diberikan secara perorangan, 3. Umpan balik yang diberikan oleh guru secara perorangan kepada setiap siswa. Dalam pengajaran latihan, peran guru adalah memberikan umpan balik kepada semua siswa, baik mereka yang telah berhasil melaksanakan tugas dengan baik, maupun yang belum berhasil dalam tugas.

Dari uraian di atas dapat dikatakan bahwa gaya mengajar latihan adalah gaya yang ditandai dengan adanya pergeseran pengambilan beberapa keputusan dari guru kepada siswa selama proses pembelajaran berlangsung. Perpindahan tersebut memberi peran dan tanggung jawab kepada siswa untuk menentukan cara dan membuat keputusan sendiri dengan tetap memperhatikan ketentuan yang ada.

Pembelajaran dengan gaya mengajar komando ditandai dengan kondisi bahwa guru paling dominan untuk membuat keputusan dalam penyusunan anatomi gaya mengajar. Siswa hanya mentaati perintah serta petunjuk yang diberikan guru. Siswa tidak diberi kesempatan untuk membuat perangkat keputusan.

Materi pelajaran disampaikan bagian demi bagian kepada siswa. Dimulai dari materi bagian pertama, selanjutnya materi bagian kedua diberikan setelah siswa menguasai materi bagian pertama, dan materi bagian ketiga diberikan setelah siswa menguasai materi bagian kedua, dan seterusnya hingga seluruh materi pelajaran selesai.

Dengan menggunakan gaya komando, maka sasaran yang akan dicapai adalah :1. Respon langsung terhadap petunjuk yang diberikan, 2. Penampilan yang sama/seragam, 3. Penampilan yang disinkronkan, 4. Penyesuaian, 5. Mengikuti metode 
yang telah ditentukan, 6. Ketepatan dan kecermatan respon, 7. Mereproduksi model, 8. Meneruskan kegiatan dan tradisi cultural, 9. Mempertahankan tingkat estetika, 10. Meningkatkan semangat kelompok, 11. Penggunaan waktu secara efisien, dan 12 . Pengawasan keamanan.

Dari uraian di atas, maka anatomi gaya mengajar komando dapat ditulis sebagai berikut.

Tabel 2. Anatomi Gaya Mengajar Komando, Mosston (1994).

\begin{tabular}{cc}
\hline Perangkat Keputusan & A \\
\hline Pra pertemuan & $(\mathrm{G})$ \\
\hline Selama pertemuan & $(\mathrm{G})$ \\
\hline Pasca pertemuan & $(\mathrm{G})$ \\
\hline
\end{tabular}

Keterangan :

$\mathrm{A}=$ Gaya komando

$\mathrm{G}=$ Guru

Memperhatikan gaya mengajar komando tersebut, terlihat bahwa setiap perangkat keputusan dibuat oleh guru. Selama proses pembelajaran, setiap siswa memperoleh kesempatan untuk mengembangkan keterampilan fisik, sosial, emosional, dan kognitif. Dalam gaya mengajar komando keterampilan fisik meningkat dengan pesat, saluran sosial, emosional, dan kognitif terbatas. Bila pelaksanaan tugas-tugas yang berkaitan dengan ingatan siswa berjalan secara mandiri, sehingga posisi siswa pada saluran kognitif pada titik maksimum. Namun sebaliknya bila siswa tidak dapat mandiri dalam melaksanakan tugas-tugasnya, maka posisi siswa pada saluran kognitifnya berada pada titik minimum.

Berikut langkah-langkah pelaksanaan gaya mengajar komando: sebelum pertemuan (pra pertemuan), semua keputusan dibuat oleh guru, terdiri dari: 1. Pokok bahasan, 2. Tugas-tugas, dan 3. Organisasi. Selama pertemuan berlangsung, perangkat keputusan dibuat oleh guru, yang mencakup : 1. Penjelasan mengenai peran guru dan siswa, 2. Penyampaian pokok bahasan, 3. Penjelasan prosedur, organisasi tentang pembagian regu dan kelompok, penempatan dalam wilayah kegiatan, perintah yang harus diikuti, 4. Urutan kegiatan meliputi peragaan, penjelasan pelaksanaan, dan penilaian. Sedangkan pada tahap pasca pertemuan, guru 1. Memberikan umpan balik langsung kepada siswa, 2. Sasarannya harus memberikan banyak waktu untuk pelaksanaan tugas.

Implikasi dari penggunaan gaya mengajar komando menurut Mosston dijabarkan sebagai berikut : 1 . Standar penampilan sudah cukup mantap dan umumnya satu model untuk satu tugas, 2. Pokok bahasan dipelajari secara meniru dan mengingat melalui penampilan, 3. Pokok bahasan dipilah-pilah menjadi bagian-bagian yang dapat ditiru, 4. Tidak ada perbedaan individual, diharapkan menirukan model. Esensi dari gaya komando adalah adanya hubungan langsung dan secepatnya antara stimulus yang disampaikan oleh guru dengan respons yang diberikan oleh siswa. Setiap gerakan yang dilakukan oleh siswa selalu mengikuti contoh-contoh yang diberikan oleh guru.

Dengan demikian yang dimasksud dengan gaya mengajar komando dalam penelitian ini adalah gaya mengajar yang pendekatannya ditandai dengan kondisi guru paling dominan dalam membuat suatu keputusan. Siswa hanya mentaati perintah serta petunjuk yang diberikan guru, siswa tidak diberi kesempatan untuk membuat perangkat keputusan. Oleh karena itu, dengan gaya mengajar komando ini peneliti bisa 
mengetahui apakah yang akan diajarkan melalui gaya mengajar komando dapat mempengaruhi siswa dalam melakukan gerakan keterampilan pukulan smash dengan baik.

Konsep diri (self concept) menurut Muijs adalah persepsi seseorang tentang dirinya sendiri, yang terbentuk melalui pengalamannya, dengan lingkungan, interaksinya dengan orang-orang lain yang memiliki arti penting (significant others), dan atribusi tentang perilakunya sendiri (Muijs dan Reynolds, 2008:218).

Secara umum instilah konsep diri merupakan gabungan dari pemikiran, perasaan, dan sikap yang dimiliki orang terhadap dirinya sendiri. Konsep diri merupakan gabungan dari seluruh keyakinan dan sikap seseorang terhadap dirinya sendiri. Selanjutnya dijelaskan bahwa konsep diri merujuk pada keyakinan, keinginan, nilai-nilai, dan sifat-sifat yang ditetapkan seseorang terhadap dirinya sendiri.

Dariyo, berpendapat bahwa konsep diri adalah gambaran diri yang bersifat menyeluruh terhadap keberadaan diri seseorang (Dariyo, 2007:202). Konsep diri adalah pandangan seseorang tentang dirinya sendiri yang menyangkut apa yang ia ketahui dan rasakan tentang perilakunya, isi pikiran dan perasaannya, serta bagaimana perilakunya tersebut berpengaruh terhadap orang lain (Djaali, 2008:129). Konsep diri yang dimaksud adalah bayangan seseorang tentang keadaan dirinya sendiri pada saat ini, dan bukanlah bayangan ideal dari dirinya sendiri sebagaimana yang diharapkan atau disukai oleh individu yang bersangkutan.

Agustiani, menjelaskan bahwa konsep diri merupakan gambaran yang dimiliki seseorang tentang dirinya, yang dibentuk melalui pengalaman-pengalaman yang diperoleh dari interaksi dengan lingkungan (Agustiani, 2006:138). Lebih lanjut mengutip pendapat Wiliam H. Fitts, menjelaskan bahwa konsep diri merupakan aspek penting dalam diri seseorang, karena konsep diri seseorang merupakan kerangka acuan (fram of reference) dalam berinteraksi dengan lingkungan. Konsep diri seseorang dapat dipengaruhi oleh beberapa faktor, antara lain : a. pengalaman, terutama pengalaman interpersonal yang memunculkan perasaan positif dan perasaan berharga; b. kompetensi dalam area yang dihargai oleh individu dan orang lain, dan c. aktualisasi diri, yakni implementasi dan relialisasi dari potensi pribadi yang sebenarnya. Secara hirarki konsep diri terbagi tiga, yakni konsep diri umum, konsep diri akademik dan konsep diri non akademik. Konsep diri umum merupakan gabungan dari konsep diri akademis dan konsep diri non akademis. Menurut Huitt, konsep diri akademik ini terdiri atas dua tingkat, yakni konsep diri akademik umum, yaitu konsep diri yang berkaitan dengan bagaimana baiknya manusia secara keseluruhan, dan konsep diri akademik spesifik, yaitu konsep diri yang berkaintan dengan baiknya manusia dalam memahami berbagai mata pelajaran di sekolah, seperti matematika, sains, bahasa, seni dan ilmu-ilmu sosial.

Konsep diri non akademik berkaitan dengan keberanian sosial, kemampuan fisik, penampilan fisik, hubungan dengan teman sebaya dan hubungan dengan keluarga (Reynolds, 2004:2). Lebih rinci konsep diri non akademik terdiri dari konsep diri sosial, konsep diri emosional dan konsep diri fisik. Konsep diri fisik menyangkut dengan kemampuan fisik dan penampilan fisik. Konsep diri sosial menyangkut hubungan dengan lingkungan dan hubungan dengan orang yang berarti baginya, seperti keluarga. Sedangkan konsep diri emosional merupakan bagian dari konsep diri psikologis. Konsep diri psikologis adalah konsep diri yang didasarkan atas pemikiran, perasaan, dan emosi yang terdiri dari kualitas, kemampuan, dan sifat-sifat yang memainkan peranan penting dalam beradaptasi dengan kehidupan seperti keberanian, kejujuran, 
kemandirian, percaya diri, harapan dan cita-cita serta jenis-jenis kemampuan lain yang berbeda. Bila ditinjau dari isinya konsep diri terdiri dari dua unsur, yakni unsur kognitif dan unsur evaluative. Unsur kognitif merupakan pengetahuan individu tentang keadaan dirinya, sedangkan unsur evaluative merupakan penilaian individu terhadap diri. Penilaian tersebut akan membentuk penerimaan terhadap diri.

Dari pendapat para pakar di atas, dapat disimpulkan bahwa, konsep diri adalah seluruh pengetahuan tentang diri sendiri, yang terdiri dari semua persepsi, perasaan, keyakinan, dan nilai-nilai yang dihubungkan dengan diri sendiri dan orang lain, baik sebagai subjek maupun sebagai objek. Konsep diri tidak terlepas dari gambaran diri, citra diri, penilaian diri, penerimaan diri, dan harga diri. Sebagaimana dinyatakan oleh Bloom, bahwa konsep diri merupakan kombinasi dari citra diri, intensitas afektif, evaluasi diri, dan predisposisi tingkah laku. Citra diri adalah apa yang dilihat seseorang ketika ia melihat pada dirinya sendiri, intensitas afektif adalah seberapa kuat seseorang merasakan tentang bermacam-macam segi gambaran diri tersebut, evaluasi diri adalah apakah seseorang mempunyai pendapat yang menyenangkan tentang bermacam-macam dari gambaran itu, dan predisposisi tingkah laku adalah apa yang kemungkinan besar bisa dibuat seseorang dalam merespons kepada evaluasi tentang dirinya sendiri.

\section{KESIMPULAN}

1. Secara keseluruhan terdapat perbedaan yang signifikan dari hasil belajar keterampilan smash bulutangkis antara kelompok siswa yang diajar dengan gaya mengajar latihan dan kelompok siswa yang diajar dengan gaya mengajar komando.

2. Hasil belajar keterampilan smash bulutangkis bagi kelompok siswa yang memiliki konsep diri tinggi yang diajar dengan gaya mengajar latihan lebih baik dibandingkan dengan kelompok siswa yang diajar dengan gaya mengajar komando.

3. Bagi siswa yang memiliki tingkat konsep diri yang rendah, tidak terdapat perbedaan yang signifikan antara gaya mengajar latihan dengan gaya mengajar komando terhadap keterampilan smash bulutangkis.

4. Terdapat interaksi yang positif antara gaya mengajar dengan konsep diri terhadap keterampilan smash bulutangkis.

Dari hasil penelitian disimpulkan bahwa baik kelompok siswa yang memiliki tingkat konsep diri tinggi maupun kelompok siswa yang memiliki tingkat konsep diri rendah dalam proses pembelajaran lebih tepat menerapkan gaya mengajar latihan.

\section{DAFTAR PUSTAKA}

Agustiani, Hendiarti. Psikologi Perkembangan: Pendekatan Ekologi Kaitannya dengan Konsep Diri dan Penyesuaian Diri pada Remaja, Bandung: Refika Aditama, 2006.

Ballou, Ralph. Badminton For Beginners, Collorado ; 8011, Morton Publishing Company, 1992.

Beckman, Pat. Strategy Instruction, 2004 http://ericec.org/digests/e638.html.

Djide, Tahir. et al. Pedoman Praktis Bermain Bulutangkis, Jakarta : PB. PBSI, 2003. 
Dick, Walter and Lou Carey, They Systematic Design of Instruction New York: Harper Collins College Publishers, 1996.

Dariyo, Agoes. Psikologi Perkembangan Anak Tiga Tahun Pertama, Bandung: PT. Refika Aditama, 2007.

Djaali, H. Psikologi Pendidikan, Jakarta: PT, Bumi Aksara, 2008.

Muijs, Daniel \& David Reynolds, Effective Teaching Evidence and Practice Second Edition, Penerjemah Helly Prajitno dan Sri Mulyantini Soetjipto. Yogyakarta: Pustaka Pelajar, 2008.

Poole, James. Belajar Bulutangkis, Bandung ; CV. Pionir Jaya, 2005.

R. Kenneth. Davidson, Lealand R. Gustavson, Winning Badminton, New York: The Ronald Press Company, 1964.

Reynolds, Jeanne Wrasman. Music Education and Student Self-Concept : A Review of Literature. 2004, http://music.arts.usf.edu/rpme/rpmereyn.htm.

Suryosubroto, B. Proses Belajar Mengajar di Sekolah: Wawasan Baru Beberapa Metode Pendukung, dan Beberapa Komponen Layanan Khusus. Jakarta: Rineka Cipta, 2009. 